\title{
Isolation of antimicrobial peptides from different plant sources: Does a general extraction method exist?
}

\author{
Anna S. Barashkova ${ }^{1 *}$ (D) and Eugene A. Rogozhin ${ }^{1,2}$
}

\begin{abstract}
Plants are good sources of biologically active compounds with antimicrobial activity, including polypeptides. Antimicrobial peptides (AMPs) represent one of the main barriers of plant innate immunity to environmental stress factors and are attracting much research interest. There are some extraction methods for isolation of AMPs from plant organs based on the type of extractant and initial fractionation stages. But most methods are directed to obtain some specific structural types of AMPs and do not allow to understand the molecular diversity of AMP inside a whole plant. In this mini-review, we suggest an optimized scheme of AMP isolation from plants followed by obtaining a set of peptides belonging to various structural families. This approach can be performed for large-scale screening of plants to identify some novel or homologous AMPs for fundamental and applied studies.
\end{abstract}

Keywords: Plants, Antimicrobial peptides, Isolation, Extraction, Liquid chromatography

\section{Background}

Plants represent a source of biologically active substances with various properties. Some of them can be applied in medicine and agriculture [1,2]. Antimicrobial peptides (AMPs) are of particular interest among all groups of substances of plant origin. AMPs have several common properties: they are small molecules with a molecular weight of $2-10 \mathrm{kDa}$ that possess amphiphilic properties, and are usually positively charged at neutral and physiological $\mathrm{pH}$ values [3, 4]. Meanwhile, AMPs have significant differences in primary and secondary structures. However, it is worth noting that most plant-based AMPs are characterized by the presence of a compact spatial structure, which is achieved by the presence of intramolecular disulfide bonds $[3,5]$. This also provides stability in relation to temperature, enzymes, and chemical agents [5]. Plant AMPs are divided into several families based

\footnotetext{
*Correspondence: barashkova.an@gmail.com

1 Shemyakin and Ovchinnikov Institute of Bioorganic Chemistry, RAS, ul. Miklukho-Maklaya, 16/10, Moscow, Russia, 117997
}

Full list of author information is available at the end of the article on the similarity of the amino acid sequence, cysteine motifs, and the location of disulfide bonds, as well as secondary structure elements $[3,4]$. The main AMP families are defensins, thionins, $\alpha$-hairpinins (hairpin-like peptides), hevein-like peptides, knottins, snakins, lipidtransfer proteins, and cyclotides. Some peptides do not belong to these families, among them peptides with unusual Cys-motif, lacking disulfide bonds, cyclic peptides without cysteine knot and glycine-, histidine-, alaninerich peptides [3,5-11]. According to the Data Repository of Antimicrobial Peptides (DRAMP) (URL: http:// dramp.cpu-bioinfor.org/browse/PlantAmpsData.php), currently, more than 800 peptides have been annotated in plants.

AMPs are an important element of the innate immunity of plants, especially to biotic stress factors [5]. AMPs have a wide spectrum of activities (antibacterial, antifungal, insecticidal, and antiviral), and some AMPs also inhibit hydrolases and protein biosynthesis [12]. Due to their chemical properties, plant AMPs also demonstrate antiproliferative action [13, 14]. The above properties of AMPs can be used for the development of new drugs or 
biological plant protection products $[9,15]$. It was established that AMPs are presented in each plant, while each species within a particular taxon (e.g., genus, family) has a certain molecular diversity of peptides belonging to different structural families [16-19]. AMPs can be obtained from all parts of plants: vegetative [20] and generative $[19,21-24]$, aboveground $[17,25,26]$ and underground [27-30]. It has been shown that the largest number and variety of AMP is isolated from seeds [9]. In this regard, seeds and fruits are of the greatest interest as sources of a diversity AMPs.

At present, transcriptomic and proteomic methods in plant AMP research are important and widely introduced [31-33]. Despite this, AMP isolation is still of relevance in investigations of structure-function relationships of AMPs at the cellular and organism levels, when the substance is required as it is [34-36]. Some new peptides that are still not involved in the actual plant AMP classification [4] have been isolated by the classical approach through extraction from plants $[7,28]$. So, it seems relevant to summarize all the experience accumulated. The presence of isolation scheme, which allows extracting a wide variety of peptides, as well as comparing the results, seems to give new opportunities in AMP research.

\section{Plant AMP isolation: general approaches}

The first AMP of plant origin was isolated by Okada and Yoshizumi from barley (Hordeum vulgare) endosperm in 1970 [37]. Since that time, many approaches to AMP extraction from plant material have been described. There are three main stages of plant AMP isolation: plant material homogenization, extraction, and saturation and purification of the extract. The extract obtained is usually fractionated by a series of liquid chromatography methods (Fig. 1). Each of these stages will be considered in detail.

\section{Plant material preparation}

AMPs can be sourced from different parts of a plant: roots, tubers, bulbs, leaves, flowers, fruits, seeds, or the whole plant. At the stage of homogenization, parts of the plant undergo mechanical destruction. Sometimes plant material is subjected to additional processing before homogenization, if necessary. Vegetative parts of plants are dried or frozen in liquid nitrogen [7, 23, 25, 27, 28], juicy fruits are cleared from seeds [22], seeds are dried, sometimes peeled, and lyophilized $[38,39]$. The disintegration method is selected due to the physical properties of the plant material. Seeds, as well as the dried parts of the plants, are ground in a coffee mill. Frozen parts of the plants are crushed in liquid nitrogen using a mortar and pestle. Fruits are ground in a blender in the presence of an extraction buffer. Some plants or their parts

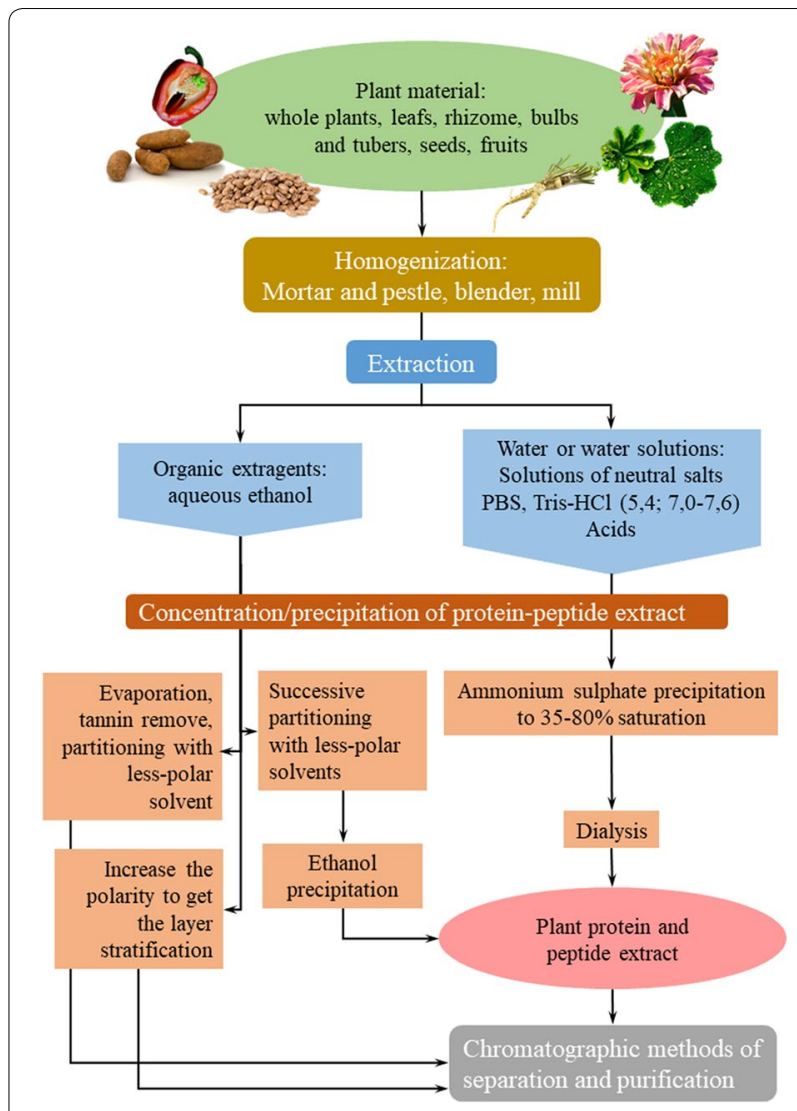

Fig. 1 Schematic diagram of AMPs isolation from different plant sources

accumulate significant content of high and/or low molecular weight metabolites: inulin in roots, storage proteins or fatty oil in seeds, and tannins in leaves and stems. If necessary, additional steps are included in the extraction process, such as heating [40], prefractionating [41], removing excess protein, defatting [42, 43], or removing of tannins [44].

\section{Choosing of solvent}

In the first publications devoted to plant AMP isolation, the general approaches to the protein isolation were implemented. Aqueous solutions of salts, buffer solutions, or diluted acids were used as extraction buffers $[45,46]$. Purothionins, the first AMPs obtained from plants, were extracted with a sulphuric acid solution [37]. In some cases, the approach developed and approved for the extraction of peptides of vertebrate origin is applied. Park and colleagues [8] used the previously developed method of AMP isolation from Asian toad (Bufo bufo gargarizans) stomach for isolation of glycine- and histidine-reach plant-derived peptides. Later, this method 
became widely applied in AMP isolation from plants [16, $24,42,47,48]$.

Currently, two groups of extractants are used to extract AMP from plant sources. The first is represented by water and water-based solutions including salt, acids, and buffer solutions; the second includes organic-based solutions, including water solutions of ethanol (Fig. 1). The most common approaches to AMP extraction are given in Table 1.

\section{Water-based solvents}

Buffer solutions are the most common extractant for the isolation of plant AMPs. The following principle of AMP extraction and further fractionation is applied. The isolation of the maximum variety of proteins and peptides occurs during the extraction process. Then, separation by mass and charge is used to obtain the peptide fraction. Finally, the characteristics of the individual components are carried out by investigation purposes, if required. Phosphate buffer is the most used extractant for AMP isolation [7, 22, 38, 49-54]. The $\mathrm{pH}$ value used is close to neutral (7.4-7.5) or low acidic, close to physiological (5.4-5.5), or lower. When working with seeds with high protein content (cereals, beans, nuts), phosphate buffer saline (PBS) is used with salt concentrations of about $100-200 \mathrm{MM} \mathrm{NaCl}$ or $\mathrm{KCl}[22,38,49,50,53]$. Tris-HCl buffer $(10 \mathrm{mM})$ at $\mathrm{pH} 7.0-7.6[17,29,41,55,56]$ and acetate buffer at pH $5.0[30,57]$ are also used.

Using the buffer solutions as extractant leads to the extraction of a wide range of polypeptides, as well as other plant metabolites, such as carbohydrates and soluble in water secondary metabolites. This reduces the total yield of the target compounds.

Water and aqueous solutions of acids Most AMPs are cationic molecules $[5,9]$. Therefore, during the extraction with aqueous solutions of acids, proteins and peptides with basic properties are extracted first, which simplifies further fractionation. Acidic AMP extraction is the method by which the first thionins from barley $(H$. vulgare) and wheat (Triticum aestivum) were isolated. Okada and Yoshizumi used sulfuric acid solution [37]. The first scheme of AMP isolation and purification was proposed simultaneously. Purification presumed a series of reprecipitations. Later, this scheme was modified and applied for defensins isolation [58]. To carry out the acidic extraction, $50 \mathrm{mM} \mathrm{H}_{2} \mathrm{SO}_{4}[23,27,37,56,58]$ and $2 \% \mathrm{CH}_{3} \mathrm{COOH}$ [59] were used. Also, $0.1 \mathrm{M} \mathrm{HCl}$ [60] in the presence of $150 \mathrm{MM} \mathrm{NaCl}$ can be used to increase the ionic strength of the solution (e.g., when sedimentation of high molecular proteins is required).

Water [28, 39, 61] or neutral salt solution [62] also can serve as solvents for AMPs extraction. The salt solution was used for the first defensin ( $\gamma$-putothionin) extraction from wheat ( $T$. aestivum) endosperm.

Some parts of the plant do not require extraction. When working with coconut water, after the selection of the material, dialysis against the water with acetic acid addition up to $\mathrm{pH} 2.0$ directly follows [63]. However, it must be emphasized that when working with plant material containing a large number of storage proteins, the purification and isolation of the peptide fraction usually requires more stages.

\section{Saturation and purification}

The next stage after extraction is the saturation and purification of the extract. When using salt buffers, water, or acid solutions as extractants, the saturation of the protein-peptidic fraction is most often carried out by salting out the solution with ammonium sulfate $[7,17,22,27,28$, $30,38,40,49-52,55,58,60]$. This is carried out in one or two stages [55], if seeds with high total protein content were used. To remove salt excess, dialysis is used. It can be held against water, buffer solution used during the extraction, or solution needed for further analysis. Dialysis is combined with primary purification of low molecular weight impurities using dialysis bags with pores of a certain size (1000-3000 cut-off). In recent years, instead of dialysis, so-called desalination (low-pressure chromatography) is applied. This technique involves the use of hydrophobic sorbents (phenyl-Sepharose, reverse phases C8, C18) $[8,16,61]$.

In some cases, the ammonium sulfate saturation is skipped, and the crude extract is fractionated. For example, hevein-like peptides can be isolated by reverse phase chromatography of the crude water extract $[39,61]$. Thionins were isolated from white mistletoe (Viscum album) by cation exchange chromatography fractionation of the acidic extract after acid neutralization [59]. A lipidtransporting protein from garden pea (Pisum sativum) was purified from crude extract after extraction and dialysis [57]. But in most cases, ammonium sulfate saturation is presented. Another method of extract saturation is the addition of trichloroacetic acid and subsequent fractionation using ammonium bicarbonate. This approach was used when the first defensin was isolated [62].

\section{Organic solvents}

Organic solvents are the second group of extractants. The most common variant is the aqueous solution of ethanol. Organic extraction is used if the purpose of the extraction is to isolate a specific group of peptides, especially cyclotides and thionins [26, 64-66]. During the extraction with organic solvents, not only peptides, but also various low molecular weight compounds are extracted to the solution. This should be considered 
Table 1 Approaches to the isolation of different structural families AMPs from various plant material

\begin{tabular}{|c|c|c|c|c|}
\hline Extractant & AMP & Plant species and part & Extraction method & Reference \\
\hline \multicolumn{5}{|l|}{ Water and water-based solutions } \\
\hline \multirow[t]{2}{*}{ Water } & New Cysteine-Rich Peptides & Potentilla anserina (roots) & $\begin{array}{l}\text { 1. Dried roots were extracted at } \\
\text { room temperature for } 1 \mathrm{~h} \text { and } \\
\text { centrifuged at } 10,000 \text { rpm for } \\
20 \text { min; } \\
\text { 2. Concentration by adding } \\
\text { ammonium sulfate to } 80 \% \text { rela- } \\
\text { tive saturation; } \\
\text { 3. Desalting was performed using } \\
\mathrm{C}_{18} \text { reversed-phase flash column } \\
\text { at a stepwise gradient of ethanol } \\
(40,60,80 \%)\end{array}$ & {$[24]$} \\
\hline & 8-Cys hevein-like peptides & Moringa oleifera, (fresh leaves) & $\begin{array}{l}\text { 1. Plant material was extracted } \\
\text { with an equal volume of water } \\
\text { while blending ( } 6 \text { min). The } \\
\text { mixture was centrifuged at } \\
8000 \text { rpm for } 10 \text { min; } \\
\text { 2. The supernatant was filtered } \\
\text { and loaded on } \mathrm{C}_{18} \text { flash-column, } \\
\text { elution was performed using } \\
\text { increase of ethanol concentra- } \\
\text { tion }(20,70 \%)\end{array}$ & [41] \\
\hline Acid solution $50 \mathrm{mM} \mathrm{H}_{2} \mathrm{SO}_{4}$ & Defensin & Nicotiana alata (flowers) & $\begin{array}{l}\text { 1. Flowers were ground with liquid } \\
\text { nitrogen by mortar and pestle, } \\
\text { then extracted with sulfuric acid } \\
\text { ( } 3 \mathrm{~mL} / \mathrm{g} \text { wet weight) for } 1 \mathrm{~h} \text {. } \\
\text { Insoluble material was filtered } \\
\text { and centrifuged }(25,000 \mathrm{~g} \text {, } \\
\left.15 \mathrm{~min}, 4^{\circ} \mathrm{C}\right) \\
\text { 2. } \mathrm{pH} \text { of supernatant was adjusted } \\
\text { to } 7.8 \text { by adding } \mathrm{NaOH} \text {, and } \\
\text { stirred for } 1 \mathrm{~h} \text {, then centrifuged } \\
\left(25,000 \mathrm{~g}, 15 \mathrm{~min}, 4^{\circ} \mathrm{C}\right) \\
\text { 3. Concentration by adding solid } \\
\text { ammonium sulfate to } 80 \% \\
\text { relative saturation (stirring for } \\
\left.4-16 \mathrm{~h} \text { at } 4{ }^{\circ} \mathrm{C}\right) \\
\text { 4. The precipitate was dissolved } \\
\text { in gel-filtration buffer, heated } \\
\text { to } 90^{\circ} \mathrm{C} \text { and separated using } \\
\text { Sephadex G-50 gel-filtration } \\
\text { column }\end{array}$ & {$[42]$} \\
\hline $\begin{array}{l}\text { Acid mixture: } 1 \% \mathrm{v} / \mathrm{v} \text { trif- } \\
\text { luoracetic acid (TFA), } 1 \mathrm{M} \mathrm{HCl} \text {, } \\
5 \% \mathrm{v} / \mathrm{v} \text { formic acid, } 1 \% \mathrm{w} / \mathrm{v} \\
\mathrm{NaCl}\end{array}$ & Gly/His-rich peptides & Capsella bursa-pastoris (roots) & $\begin{array}{l}\text { 1. Roots were homogenized } \\
\text { while blending with extraction } \\
\text { mixture }(1: 4, \mathrm{w}: \mathrm{v}) \text {. Homogenate } \\
\text { was filtered through a paper } \\
\text { filter and centrifuged at 20,000g } \\
30 \text { min } \\
\text { 2. The supernatant was concen- } \\
\text { trated using the reversed-phase } \\
\mathrm{C}_{18} \text { Sep-Pack cartridge. Peptides } \\
\text { were removed from the column } \\
\text { by washing with } 80 \% \text { acetoni- } \\
\text { trile with } 0.1 \% \text { TFA }\end{array}$ & [6] \\
\hline
\end{tabular}


Table 1 (continued)

\begin{tabular}{|c|c|c|c|c|}
\hline Extractant & AMP & Plant species and part & Extraction method & Reference \\
\hline $\begin{array}{l}\text { Buffer solution: } 0.1 \text { M Tris-HCl } \\
\text { (pH 7.2) }\end{array}$ & Defensin-like peptides & Phaseolus limensis (seeds) & $\begin{array}{l}\text { 1. Seeds were washed and soaked } \\
\text { in water for } 12 \mathrm{~h} \text {. Then homoge- } \\
\text { nated in a blender with buffer } \\
\text { solution. The homogenate was } \\
\text { centrifuged at } 12,000 \text { rpm for } \\
20 \text { min at } 4{ }^{\circ} \mathrm{C} \text {; } \\
\text { 2. The supernatant was fraction- } \\
\text { ated by two-step ammonium } \\
\text { sulfate precipitation. In the first } \\
\text { step, the solution was saturated } \\
\text { to } 20 \% \text {; the resulting superna- } \\
\text { tant was saturated to } 85 \% \\
\text { 3. After centrifugation at } \\
12,000 \text { rpm for } 20 \text { min, the pre- } \\
\text { cipitate was collected, dissolved } \\
\text { in } 100 \mathrm{~mL} \text { of } 0.01 \mathrm{M} \text { Tris-HCl } \\
\text { buffer ( } \mathrm{pH} 7.2) \text {, and dialyzed } \\
\text { against the same buffer and sub- } \\
\text { jected to the further separation }\end{array}$ & [43] \\
\hline $\begin{array}{l}\text { Buffer solution: } 10 \mathrm{mM} \mathrm{Na}_{2} \mathrm{HPO}_{4} \text {, } \\
15 \mathrm{mM} \mathrm{NaH}{ }_{2} \mathrm{PO}_{4}, 100 \mathrm{mM} \mathrm{KCl}^{\prime} \\
1,5 \% \text { EDTA, pH } 5.4\end{array}$ & Thionin-like peptides & $\begin{array}{l}\text { Capsicum anuum (Fruits without } \\
\text { seeds) }\end{array}$ & $\begin{array}{l}\text { 1. C. anuum fruits were extracted } \\
\text { with a buffer solution in a } 1 \text { to } 5 \\
\text { ratio (w:v) for } 2 \text { h; } \\
\text { 2. The extract was saturated } \\
\text { with ammonium sulfate. The } \\
\text { precipitate formed between } 0 \\
\text { and } 70 \% \text { relative saturation was } \\
\text { redissolved in distilled water and } \\
\text { heated at } 80^{\circ} \mathrm{C} \text { for } 15 \text { min and } \\
\text { centrifuged; } \\
\text { 3. The resulting suspension was } \\
\text { extensively dialyzed against } \\
\text { distilled water, freeze-dried and } \\
\text { subjected to further fractiona- } \\
\text { tion by the chromatographic } \\
\text { method }\end{array}$ & [18] \\
\hline \multicolumn{5}{|l|}{ Organic solutions } \\
\hline $\begin{array}{l}\mathrm{MeOH} / \mathrm{CH}_{2} \mathrm{Cl} / 0.05 \% \text { TFA in water } \\
(4: 4: 1)\end{array}$ & PawS-derived peptides & Zinnia haageana (seeds) & $\begin{array}{l}\text { 1. Seeds ( } 50 \mathrm{mg} \text { ) were ground to } \\
\text { a fine powder with mortar and } \\
\text { pestle under liquid nitrogen with } \\
\text { a pinch of } 0.1 \mathrm{~mm} \text { glass beads; } \\
\text { 2. The extraction mixture ( } 0.9 \mathrm{~mL} \text { ) } \\
\text { was added to the seed powder, } \\
\text { and the mixture was vortexed } \\
\text { and centrifuged ( } 3 \text { min at } \\
16,000 \mathrm{~g} \text { ). If the phases were not } \\
\text { separated at this point, } 0.1 \mathrm{~mL} \\
\text { of chloroform or } 0.1 \mathrm{~mL} \text { of } \\
0.05 \% \text { TFA in water was added } \\
\text { alternately, followed by short } \\
\text { centrifugation after each addi- } \\
\text { tion, until phase separation was } \\
\text { achieved; } \\
\text { 3. After phase separation, the } \\
\text { upper polar layer was collected, } \\
\text { and dried under vacuum and } \\
\text { re-dissolved in } 0.5 \mathrm{~mL}, 5 \%(\mathrm{v} / \mathrm{v}) \\
\text { formic acid for the further pep- } \\
\text { tide identification }\end{array}$ & {$[44]$} \\
\hline $\begin{array}{l}\mathrm{EtOH} \text { or } \mathrm{MeOH} 20 \% \text { or } 50 \% \text { in } \\
\text { water respectively }\end{array}$ & Cyclotydes & Viola odorata (aerial parts) & $\begin{array}{l}\text { 1. Dried plant material was finely } \\
\text { ground; } \\
\text { 2. Plant material was extracted } \\
\text { with an extraction mixture in a } 1 \\
\text { to } 20(\mathrm{w}: \mathrm{v}) \text { ratio for } 6 \mathrm{~h}\end{array}$ & [45] \\
\hline
\end{tabular}


Table 1 (continued)

\begin{tabular}{|c|c|c|c|c|}
\hline Extractant & AMP & Plant species and part & Extraction method & Reference \\
\hline $\mathrm{MeOH}$ in water $(1: 1)$ & Thionins & $\begin{array}{l}\text { Viscum album (Green and white } \\
\text { parts) }\end{array}$ & $\begin{array}{l}\text { 1. Plant material was crushed, } \\
\text { the extraction mixture was } \\
\text { added (1:5, w:v), the solution } \\
\text { was filtered and its volume was } \\
\text { reduced; } \\
\text { 2. The aqueous phase was } \\
\text { successively partitioned with } \\
\text { cyclohexane, dichloromethane, } \\
\text { and ethyl acetate; } \\
\text { 3. Ethanol was added to the } \\
\text { concentrated aqueous phase to } \\
\text { achieve } 85 \% \text { (v/v) concentration; } \\
\text { the precipitate was separated by } \\
\text { centrifuging (2000g; } 10 \text { min); } \\
\text { 4. The supernatant was concen- } \\
\text { trated, and ethanol was added } \\
\text { to } 85 \% \text { ( } / \mathrm{v} \text { ). The precipitates } \\
\text { were pooled }\end{array}$ & {$[46]$} \\
\hline
\end{tabular}

when purifying the resulting extract. The methods of purification, fractionation, and further saturation of the extract can vary (Fig. 1). An extraction scheme of cyclotides was proposed by Claeson et al. [44]. This involved the pretreatment of plant material and additional purification. According to this scheme, plant material was crushed and treated by $\mathrm{CH}_{2} \mathrm{Cl}_{2}$. After treatment, the material was subjected to extraction with aqueous ethanol, and the extract obtained was purified from tannins on a column with polyamide in acidic conditions $[25,44]$. Later, this scheme was improved through the optimization of ethanol to water ratio in the extracting solution, the ratio of plant material and extractant, as well as the time and number of repeated extractions [67].

The organic extraction method can be applied to the isolation of other cyclic peptides. In this case, the separation of the peptide fraction is achieved by increasing the polarity of the solution by adding the acid [10]. When using organic solvents for thionins isolation, the aqueous-methanolic extract is subjected to successively partition with solvents of increasing polarity (cyclohexane $\rightarrow$ dichloromethane $\rightarrow$ ethyl acetate), followed by precipitation by saturation of the solution with ethanol to $85 \%[66]$.

The use of organic solvents for AMP isolation is simple and relatively cheap, and also allows the analysis of small amounts of plant material [10]. However, it is worth noting that when using organic extractants, a limited amount of substances passes into the solution as a whole. At the same time, with a targeted search for AMP substances with certain properties, this method is easier than extraction with aqueous solutions due to the simplification of the fractionation procedure.
The next most common stage of purification of a protein-peptide extract following concentration is the separation by cation exchange chromatography in a linear or stepwise gradient of $\mathrm{NaCl}$.

\section{Plant AMP isolation: Optimized approach}

An optimized scheme of AMP isolation from plants was proposed in the Laboratory of Neuroreceptors and Neuroregulators of the Institute of Bioorganic Chemistry of the Russian Academy of Sciences (Fig. 2). Acetic acid $(10 \%)$ is proposed as the extractant. This scheme was used for the extraction of AMPs belonging to different families: $\alpha$-hairpinins [68-71], defensins [19, 48, 72], thionins [73, 74], and hevein-like peptides [20,75]. Also, peptides that do not belong to main families were isolated using this scheme, and partially characterized [21, $76,77]$.

\section{Plant preparation and extraction}

According to this scheme, plant material is ground in a coffee mill or blender. The extractant used is $10 \%$ $\mathrm{CH}_{3} \mathrm{COOH}$ with the addition of a commercial cocktail of proteinase inhibitors (Sigma-Aldrich, USA). This is added to the ground material at a 1:10 (w:v) ratio. Extraction is carried out with constant vigorous stirring for $1 \mathrm{~h}$ at room temperature. The mixture is passed through the sieve; fine particles are separated by centrifuging at $4700 \mathrm{rpm}$ for $10 \mathrm{~min}$. The supernatant is filtered through a Whatman paper filter. When large amounts are studied, the resulting supernatant is additionally concentrated approximately 1.5-2-times on a rotary evaporator. 


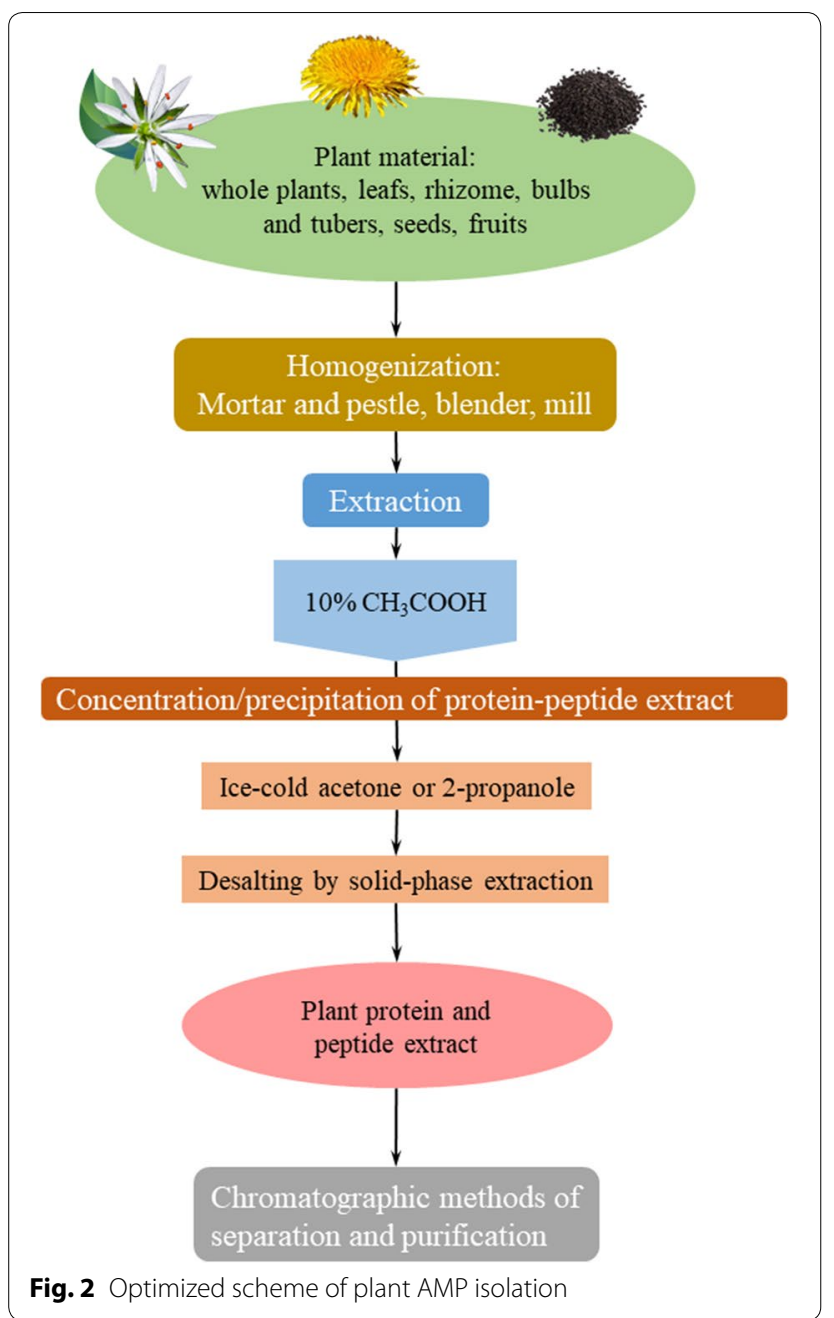

\section{Precipitation}

Organic solvent precipitation is used as a saturation method. Cold acetone $\left(-70{ }^{\circ} \mathrm{C}\right)$ is poured into the filtrate at a 1:7 ratio while gently stirring; then, the mixture is placed at $+4{ }^{\circ} \mathrm{C}$ for $6-8 \mathrm{~h}$. After this time, the supernatant is discarded, and if necessary, the suspension is centrifuged at $4700 \mathrm{rpm}$ for $10 \mathrm{~min}$ to collect the precipitated fraction. The fraction obtained is dried at room temperature. The dried precipitate was redissolved in $0.1 \%$ TFA and purified from low molecular weight components by solid-phase extraction by medium or high-pressure liquid chromatography on a C8 column. The resulting desalted protein-peptide extract is evaporated using a vacuum centrifuge and lyophilized. The obtained lyophilisate can be used in antimicrobial activity tests or subjected to further fractionation. It is worth noting that due to the abandonment of the method of salting out with ammonium sulfate in favour of precipitation with an organic solvent, the described technique allows for the avoidance of dialysis. Thus, the loss of substance can be avoided, and the extraction time can be significantly reduced.

\section{Fractionation}

For further fractionation, the following scheme was proposed. This can be simplified depending on the specific conditions (mainly, the type of biological material used). In the first phase, the fractionation is done by affinity chromatography using heparin-Sepharose sorbent as a solid phase using increasing concentrations of $\mathrm{NaCl}$. This provides the separation of the mixture components by a charge from negatively charged to highly cationic. Solid-phase desalting is carried out. The second step is size exclusion chromatography. This is necessary for plant material with a large amount of total protein, especially for seeds. Sometimes, step two can be avoided if the plant material does not contain reserve proteins. The last step is the fractionating of the mixture by reversed-phase chromatography.

\section{Conclusion}

Antimicrobial peptides can be isolated from plants in various ways, and the experimental conditions can be adapted to the extraction of certain peptides or representatives of peptide families. This approach can be positioned as intensive. However, it eliminates the possibility of screening plants for a wide variety of AMPs, especially potentially undiscovered AMPs. Components of the protein-peptide extract that are not of a special purpose mainly remain unclaimed. The plant AMPs isolation scheme proposed in our group allowed us to obtain and characterize a larger structural diversity of antimicrobial peptides than is represented in most publications on this subject. Nevertheless, some AMPs require alternative isolation approaches (e.g., cyclotides can serve as an example).

Thus, we conclude that there is no universal scheme allowing the isolation of AMPs of all structural families from plants. However, there are two general approaches: cyclic peptides isolation and the isolation of representatives of various AMP families (optimized extraction scheme). Using these algorithms and their optimization can provide a fairly complete diversity of the composition of plant AMPs.

\section{Acknowledgements \\ Not applicable.}

\section{Authors' contributions}

$A B$ designed the review and wrote the first draft of the manuscript. ER reviewed and edited the manuscript. All authors contributed to manuscript revision. Both authors read and approved the final manuscript. 


\section{Funding}

This work was supported by the Russian Science foundation (Grant No. 18-7410073) (section devoted to "AMP isolation: Basic Approaches") and the Russian Foundation for Basic Research (Grant No. 18-74-20058) (section devoted to "AMP isolation: Optimized Approaches").

\section{Availability of data and materials}

Not applicable.

Ethics approval and consent to participate

Not applicable.

\section{Consent for publication}

Not applicable.

\section{Competing interests}

The authors declared that they have no competing interests.

\section{Author details}

${ }^{1}$ Shemyakin and Ovchinnikov Institute of Bioorganic Chemistry, RAS, ul. Miklukho-Maklaya, 16/10, Moscow, Russia, $117997 .{ }^{2}$ Gause Institute of New Antibiotics, ul. Bolshaya Pirogovskaya, 11, Moscow, Russia 119021.

Received: 8 June 2020 Accepted: 17 October 2020

\section{Published online: 23 October 2020}

\section{References}

1. Yan J, Yuan SS, Jiang LL, Ye XJ, Ng TB, Wu ZJ. Plant antifungal proteins and their applications in agriculture. Appl Microbiol Biotechnol. 2015. https:// doi.org/10.1007/s00253-015-6654-6.

2. Dhama K, Karthik K, Khandia R, Munjal A, Tiwari R, Rana R, et al. Medicinal and therapeutic potential of herbs and plant metabolites/extracts countering viral pathogens-current knowledge and future prospects. Curr Drug Metab. 2018;19(3):236-63.

3. Tang SS, Prodhan ZH, Biswas SK, Le CF, Sekaran SD. Antimicrobial peptides from different plant sources: isolation, characterisation, and purification. Phytochemistry. 2018;154:94-105.

4. Tam JP, Wang S, Wong KH, Tan WL. Antimicrobial peptides from plants. Pharmaceuticals. 2015;8:711-57

5. Campos ML, De Souza CM, De Oliveira KBS, Dias SC, Franco OL. The role of antimicrobial peptides in plant immunity. J Exp Bot. 2018;69:4997-5011.

6. García-Olmedo F, Molina A, Alamillo JM, Rodriguez-Palenzuéla P. Plant defense peptides. Biopolymers. 1998;47:479-91.

7. AlAkeel R, Mateen A, Syed R, Alqahtani MS, Alqahtani AS. Alanine rich peptide from Populus trichocarpa inhibit growth of Staphylococcus aureus via targetting its extracellular domain of Sensor Histidine Kinase YycGex protein. Microb Pathog. 2018;121:115-22. https://doi. org/10.1016/j.micpath.2018.05.010.

8. Park CJ, Park CB, Hong SS, Lee HS, Lee SY, Kim SC. Characterization and CDNA cloning of two glycine- and histidine-rich antimicrobial peptides from the roots of shepherd's purse, Capsella bursa-pastoris. Plant Mol Biol. 2000;44:187-97.

9. Finkina El, Melnikova DN, Bogdanov IV, Ovchinnikova TV. Peptides of the innate immune system of plants. Part I. Structure, biological activity, and mechanisms of action. Russ J Bioorganic Chem. 2018:44:573-85.

10. Franke B, Jayasena AS, Fisher MF, Swedberg JE, Taylor NL, Mylne JS, et al. Diverse cyclic seed peptides in the Mexican zinnia (Zinnia haageana). Biopolymers. 2016;106:806-17

11. Tailor RH, Acland DP, Attenborough S, Cammue BPA, Evans IJ, Osborn RW, et al. A novel family of small cysteine-rich antimicrobial peptides from seed of Impatiens balsamina is derived from a single precursor protein. J Biol Chem. 1997;272:24480-7.

12. Finkina El, Melnikova DN, Bogdanov IV, Ovchinnikova TV. Peptides of the innate immune system of plants. Part II. Biosynthesis, biological functions, and possible practical applications. Russ J Bioorganic Chem. 2019:45:55-65.

13. Parisi K, Shafee TMA, Quimbar P, van der Weerden NL, Bleackley MR, Anderson MA. The evolution, function and mechanisms of action for plant defensins. Semin Cell Dev Biol. 2019;88:107-18. https://doi. org/10.1016/j.semcdb.2018.02.004.

14. Odintsova TI, Slezina MP, Istomina EA. Plant thionins: structure, biological functions and potential use in biotechnology. Vavilovskii Zhurnal Genet Selektsii. 2018:22:667-75.

15. De Souza Cândido E, Silva Cardoso MH, Sousa DA, Viana JC, De Oliveira-

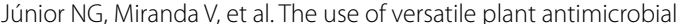
peptides in agribusiness and human health. Peptides. 2014;55:65-78.

16. Dias GB, Gomes VM, Pereira UZ, Ribeiro SFF, Carvalho AO, Rodrigues R, et al. Isolation, characterization and antifungal activity of proteinase inhibitors from Capsicum chinense Jacq. seeds. Protein J. 2013;32:15-26.

17. Teixeira FR, Lima MCOPOP, Almeida HO, Romeiro RS, Silva DJHH, Pereira PRGG, et al. Bioprospection of cationic and anionic antimicrobial peptides from bell pepper leaves for inhibition of Ralstonia solanacearum and Clavibacter michiganensis ssp. michiganensis growth. J Phytopathol. 2006;154:418-21. https://doi.org/10.1111/j.1439-0434.2006.01119.x.

18. Kul'Ko AB, Kisil OV, Sadykova VS, Mikhailov VF, Vasilieva IM, Shulenina LV, et al. Investigation of thionins from black cumin (Nigella sativa L.) seeds showing cytotoxic, regulatory and antifungal activity. Antibiot i Khimioterapiya. 2016:61:8-16.

19. Rogozhin EA, Oshchepkova YI, Odintsova TI, Khadeeva NV, Veshkurova ON, Egorov TA, et al. Novel antifungal defensins from Nigella sativa L. seeds. Plant Physiol Biochem. 2011;49:131-7. https://doi.org/10.1016/j. plaphy.2010.10.008

20. Rogozhin EA, Slezina MP, Slavokhotova AA, Istomina EA, Korostyleva TV, Smirnov AN, et al. A novel antifungal peptide from leaves of the weed Stellaria media L. Biochimie. 2015;116:125-32. https://doi.org/10.1016/j. biochi.2015.07.014.

21. Astafieva AA, Enyenihi AA, Rogozhin EA, Kozlov SA, Grishin EV, Odintsova $\mathrm{Tl}$, et al. Novel proline-hydroxyproline glycopeptides from the dandelion (Taraxacum officinale Wigg.) flowers: de novo sequencing and biological activity. Plant Sci. 2015;238:323-9. https://doi.org/10.1016/j.plant sci.2015.07.002

22. Taveira GB, Da Motta OV, Machado OLT, Rodrigues R, Carvalho AO, Teixeira-Ferreira A, et al. Thionin-like peptides from Capsicum annuum fruits with high activity against human pathogenic bacteria and yeasts. Biopolym - Pept Sci Sect. 2014;102:30-9.

23. Van Der Weerden NL, Lay FT, Anderson MA. The plant defensin, NaD1, enters the cytoplasm of Fusarium oxysporum hyphae. J Biol Chem. 2008;283:14445-52.

24. Odintsova TI, Korostyleva TV, Odintsova MS, Pukhalsky VA, Grishin EV, Egorov TA. Analysis of Triticum boeoticum and Triticum urartu seed defensins: to the problem of the origin of polyploid wheat genomes. Biochimie. 2008;90:939-46.

25. Broussalis AM, Göransson U, Coussio JD, Ferraro G, Martino V, Claeson P. First cyclotide from Hybanthus (Violaceae). Phytochemistry. 2001:58:47-51.

26. Jennings C, West J, Waine C, Craik D, Anderson M. Biosynthesis and insecticidal properties of plant cyclotides: the cyclic knotted proteins from Oldenlandia affinis. Proc Natl Acad Sci USA. 2001;98:10614-9.

27. Kovaleva V, Kiyamova R, Cramer R, Krynytskyy H, Gout I, Filonenko V, et al. Purification and molecular cloning of antimicrobial peptides from Scots pine seedlings. Peptides. 2009;30:2136-43.

28. Shen Y, Xu L, Huang J, Serra A, Yang H, Tam JP. Potentides: new CysteineRich Peptides with Unusual Disulfide Connectivity from Potentilla anserina. ChemBioChem. 2019;20:1995-2004.

29. Moreno M, Segura A, García-Olmedo F. Pseudothionin-St1, a potato peptide active against potato pathogens. Eur J Biochem. 1994;223:135-9.

30. Fujimura M, Ideguchi M, Minami Y, Watanabe K, Tadera K. Purification, characterization, and sequencing of novel antimicrobial peptides, Tu-AMP 1 and Tu-AMP 2, from bulbs of tulip (Tulipa gesneriana L.). Biosci Biotechnol Biochem. 2004;68:571-7.

31. Pires ÁS, Rigueiras PO, Dohms SM, Porto WF, Franco OL. Structure-guided identification of antimicrobial peptides in the spathe transcriptome of the non-model plant, arum lily (Zantedeschia aethiopica). Chem Biol Drug Des. 2019:93:1265-75. https://doi.org/10.1111/cbdd.13498.

32. Shelenkov A, Slavokhotova A, Odintsova T. Predicting antimicrobial and other cysteine-rich peptides in 1267 plant transcriptomes. Antibiotics. 2020;9:60.

33. Tsekouras V, Mavrikou S, Vlachakis D, Makridakis M, Stroggilos R, Zoidakis $J$, et al. Proteome analysis of leaf, stem and callus in Viscum album and 
identification of lectins and viscotoxins with bioactive properties. Plant Cell Tissue Organ Cult. 2020;141:167-78.

34. Hayes BME, Bleackley MR, Anderson MA, van der Weerden NL. The plant defensin NaD1 enters the cytoplasm of Candida albicans via endocytosis. J Fungi. 2018:4:1-15.

35. Schmidt M, Arendt EK, Thery TLC. Isolation and characterisation of the antifungal activity of the cowpea defensin Cp-thionin II. Food Microbiol. 2019;82:504-14

36. Dancewicz K, Slazak B, Kiełkiewicz M, Kapusta M. Behavioral and physiological effects of Viola spp. cyclotides on Myzus persicae (Sulz.). J Insect Physiol. 2020. https://doi.org/10.1016/j.jinsphys.2020.104025.

37. Okada T, Yoshizumi H. A lethal toxic substance for brewing yeast in wheat and barley: part II isolation and some properties of toxic principle. Agric Biol Chem. 1970;34:1089-94.

38. Osborn RW, De Samblanx GW, Thevissen K, Goderis I, Torrekens S, Van Leuven F, et al. Isolation and characterisation of plant defensins from seeds of Asteraceae, Fabaceae, Hippocastanaceae and Saxifragaceae. FEBS Lett. 1995;368:257-62.

39. Wong KH, Tan WL, Kini SG, Xiao T, Serra A, Sze SK, et al. Vaccatides: antifungal glutamine-rich hevein-like peptides from Vaccaria hispanica. Front Plant Sci. 2017;8:1100.

40. dos Santos LA, Taveira GB, Ribeiro SFF, Pereira LS, Carvalho AO, Rodrigues $\mathrm{R}$, et al. Purification and characterization of peptides from Capsicum annuum fruits which are a-amylase inhibitors and exhibit high antimicrobial activity against fungi of agronomic importance. Protein Expr Purif. 2017;132:97-107.

41. Chan YS, Ng TB. Northeast red beans produce a thermostable and pHstable defensin-like peptide with potent antifungal activity. Cell Biochem Biophys. 2013;66:637-48.

42. Egorov TA, Odintsova TI, Pukhalsky VA, Grishin EV. Diversity of wheat antimicrobial peptides. Peptides. 2005:26:2064-73.

43. Evaristus NA, Wan Abdullah WN, Gan CY. Extraction and identification of a-amylase inhibitor peptides from Nephelium lappacheum and Nephelium mutabile seed protein using gastro-digestive enzymes. Peptides. 2018;102:61-7. https://doi.org/10.1016/j.peptides.2018.03.001.

44. Claeson P, Göransson U, Johansson S, Luijendijk T, Bohlin L. Fractionation protocol for the isolation of polypeptides from plant biomass. J Nat Prod. 1998:61:77-81.

45. Barber D, Limas GG, Gavilanes JG, Méndez E. Isolation and characterization of thirteen new salt-soluble proteins from barley by reversed-phase high-performance liquid chromatography. Planta. 1988;176:221-9.

46. Limas GG, Salinas M, Moneo I, Fischer S, Wittmann-Liebold B, Méndez E. Purification and characterization of ten new rice $\mathrm{NaCl}$-soluble proteins: identification of four protein-synthesis inhibitors and two immunoglobulin-binding proteins. Planta. 1990;181:1-9.

47. Odintsova TI, Egorov TA, Musolyamov AK, Odintsova MS, Pukhalsky VA, Grishin EV. Seed defensins from Triticum kiharae and related species: genome localization of defensin-encoding genes. Biochimie. 2007:89:605-12.

48. Odintsova TI, Rogozhin EA, Baranov Y, Musolyamov AK, Yalpani N, Egorov $T A$, et al. Seed defensins of barnyard grass Echinochloa crusgalli (L.) Beauv. Biochimie. 2008;90:1667-73. https://doi.org/10.1016/j.biochi.2008.06.007.

49. Marcus JP, Goulter KC, Green JL, Harrison SJ, Manners JM. Purification, characterisation and CDNA cloning of an antimicrobial peptide from Macadamia integrifolia. Eur J Biochem. 1997;244:743-9.

50. Park SS, Abe K, Kimura M, Urisu A, Yamasaki N. Primary structure and allergenic activity of trypsin inhibitors from the seeds of buckwheat (Fagopyrum esculentum Moench). FEBS Lett. 1997;400:103-7.

51. Li F, Yang $X$, Xia H, Zeng R, Hu W, Li Z, et al. Purification and characterization of Luffin P1, a ribosome-inactivating peptide from the seeds of Luffa cylindrica. Peptides. 2003;24:799-805.

52. Harrison SJ, Marcus JP, Goulter KC, Green JL, Maclean DJ, Manners JM. An antimicrobial peptide from the Australian native Hardenbergia violacea provides the first functionally characterised member of a subfamily of plant defensins. Aust J Plant Physiol. 1997;24:571-8.

53. Melnikova DN, Mineev KS, Finkina El, Arseniev AS, Ovchinnikova TV. A novel lipid transfer protein from the dill Anethum graveolens L.: isolation, structure, heterologous expression, and functional characteristics. J Pept Sci. 2016;22:59-66.
54. Akkerdaas J, Finkina El, Balandin SV, Santos Magadán S, Knulst A, Fernandez-Rivas M, et al. Lentil (Lens culinaris) lipid transfer protein Len C 3: a novel legume allergen. Int Arch Allergy Immunol. 2011;157:51-7.

55. Wang S, Rao P, Ye X. Isolation and biochemical characterization of a novel leguminous defense peptide with antifungal and antiproliferative potency. Appl Microbiol Biotechnol. 2009;82:79-86.

56. Terras FR, Eggermont K, Kovaleva V, Raikhel NV, Osborn RW, Kester A, et al. Small cysteine-rich antifungal proteins from radish: their role in host defense. Plant Cell. 1995;7:573-88.

57. Bogdanov IV, Shenkarev ZO, Finkina El, Melnikova DN, Rumynskiy El, Arseniev AS, et al. A novel lipid transfer protein from the pea Pisum sativum: isolation, recombinant expression, solution structure, antifungal activity, lipid binding, and allergenic properties. BMC Plant Biol. 2016;16:107. https://doi.org/10.1186/s12870-016-0792-6.

58. Lay FT, Brugliera F, Anderson MA. Isolation and properties of floral defensins from ornamental tobacco and petunia. Plant Physiol. 2003;131:1283-93.

59. Schaller G, Urech K, Giannattasio M. Cytotoxicity of different viscotoxins and extracts from the European subspecies of Viscum album L. Phyther Res. 1996;10:473-7.

60. Franco OL, Murad AM, Leite JR, Mendes PAM, Prates MV, Bloch C. Identification of a cowpea $\gamma$-thionin with bactericidal activity. FEBS J. 2006;273:3489-97.

61. Kini SG, Wong KH, Tan WL, Xiao T, Tam JP. Morintides: cargo-free chitinbinding peptides from Moringa oleifera. BMC Plant Biol. 2017;17:1-13.

62. Colilla FJ, Rocher A, Mendez E. Y-Purothionins: amino acid sequence of two polypeptides of a new family of thionins from wheat endosperm. FEBS Lett. 1990;270:191-4.

63. Mandal SM, Dey S, Mandal M, Sarkar S, Maria-Neto S, Franco OL. Identification and structural insights of three novel antimicrobial peptides isolated from green coconut water. Peptides. 2009:30:633-7.

64. Craik DJ, Daly NL, Bond T, Waine C. Plant cyclotides: a unique family of cyclic and knotted proteins that defines the cyclic cystine knot structural motif. J Mol Biol. 1999;294:1327-36.

65. Slazak B, Kapusta M, Strömstedt AA, Słomka A, Krychowiak M, Shariatgorji $M$, et al. How does the sweet violet (Viola odorata l.) fight pathogens and pests-cyclotides as a comprehensive plant host defense system. Front Plant Sci. 2018:9:1296.

66. Tabiasco J, Pont F, Fournié JJ, Vercellone A. Mistletoe viscotoxins increase natural killer cell-mediated cytotoxicity. Eur J Biochem. 2002;269:2591-600.

67. Yeshak MY, Burman R, Eriksson C, Göransson U. Optimization of cyclotide extraction parameters. Phytochem Lett. 2012;5:776-81.

68. Nolde SB, Vassilevski AA, Rogozhin EA, Barinov NA, Balashova TA, Samsonova OV, et al. Disulfide-stabilized helical hairpin structure and activity of a novel antifungal peptide ECAMP1 from seeds of barnyard grass (Echinochloa crus-galli). J Biol Chem. 2011;286:25145-53.

69. Ryazantsev DY, Rogozhin EA, Dimitrieva TV, Drobyazina PE, Khadeeva NV, Egorov TA, et al. A novel hairpin-like antimicrobial peptide from barnyard grass (Echinochloa crusgalli L.) seeds: structure-functional and molecular-genetics characterization. Biochimie. 2014;99:63-70. https:// doi.org/10.1016/j.biochi.2013.11.005.

70. Utkina LL, Andreev YA, Rogozhin EA, Korostyleva TV, Slavokhotova AA Oparin PB, et al. Genes encoding 4-Cys antimicrobial peptides in wheat Triticum kiharae Dorof et Migush: multimodular structural organization, instraspecific variability, distribution and role in defence. FEBS J. 2013:280:3594-608.

71. Slavokhotova AA, Rogozhin EA, Musolyamov AK, Andreev YA, Oparin PB, Berkut AA, et al. Novel antifungal a-hairpinin peptide from Stellaria media seeds: structure, biosynthesis, gene structure and evolution. Plant Mol Biol. 2014;84:189-202.

72. Slavokhotova AA, Odintsova TI, Rogozhin EA, Musolyamov AK, Andreev YA, Grishin EV, et al. Isolation, molecular cloning and antimicrobial activity of novel defensins from common chickweed (Stellaria media L.) seeds. Biochimie. 2011;93:450-6. https://doi.org/10.1016/j.biochi.2010.10.019.

73. Slezina MP, Istomina EA, Odintsova TI. Thionins of wheat Triticum kiharae Dorof. Et Migush. Are novel potent inhibitors of Candida albicans (C.P. Robin) berkhout. Sel'skokhozyaistvennaya Biol. 2019;54:169-77.

74. Vasilchenko AS, Smirnov AN, Zavriev SK, Grishin EV, Vasilchenko AV, Rogozhin EA. Novel Thionins from Black Seed (Nigella sativa L.) Demonstrate Antimicrobial. Int J Pept Res Ther. 2016;23:171-80. 
75. Odintsova TI, Vassilevski AA, Slavokhotova AA, Musolyamov AK, Finkina El, Khadeeva NV, et al. A novel antifungal hevein-type peptide from Triticum kiharae seeds with a unique 10-cysteine motif. FEBS J. 2009;276:4266-75.

76. Astafieva AA, Rogozhin EA, Odintsova TI, Khadeeva NV, Grishin EV, Egorov TA. Discovery of novel antimicrobial peptides with unusual cysteine motifs in dandelion Taraxacum officinale Wigg. flowers. Peptides. 2012;36:266-71. https://doi.org/10.1016/j.peptides.2012.05.009.

77. Astafieva AA, Rogozhin EA, Andreev YA, Odintsova TI, Kozlov SA, Grishin EV, et al. A novel cysteine-rich antifungal peptide ToAMP4 from Taraxacum officinale Wigg. flowers. Plant Physiol Biochem. 2013;70:93-9.

\section{Publisher's Note}

Springer Nature remains neutral with regard to jurisdictional claims in published maps and institutional affiliations.
Ready to submit your research? Choose BMC and benefit from:

- fast, convenient online submission

- thorough peer review by experienced researchers in your field

- rapid publication on acceptance

- support for research data, including large and complex data types

- gold Open Access which fosters wider collaboration and increased citations

- maximum visibility for your research: over $100 \mathrm{M}$ website views per year

At BMC, research is always in progress.

Learn more biomedcentral.com/submissions 